\title{
Cyclooxygenase-2 selective inhibition with NS-398 suppresses proliferation and invasiveness and delays liver metastasis in colorectal cancer
}

\author{
M Yao', EC Lam', CR Kelly', W Zhou' and MM Wolfe,', \\ 'Section of Gastroenterology, Boston University School of Medicine and Boston Medical Center, 650 Albany Street, Boston, MA 02I I 8, USA
}

Nonsteroidal anti-inflammatory drugs (NSAIDs) have been reported to reduce the risk and mortality of colorectal cancer (CRC) by inhibiting the activity of cyclooxygenase (COX). The present studies were directed to determine whether selective COX-2 inhibition reduces CRC tumour cell proliferation and invasion/migration, and the possible cellular and molecular mechanisms involved. The MC26 cells are a highly invasive mouse CRC cell line expressing COX-2 protein. NS-398 ( $00 \mu \mathrm{M}$ ), a highly selective COX-2 inhibitor, decreased cell proliferation by $\sim 35 \%$ of control, as determined using $\left[{ }^{3} \mathrm{H}\right]$-thymidine incorporation. This reduction in cell proliferation was associated with decreased expression of cyclin DI and proliferating cell nuclear antigen (PCNA). Furthermore, NS398 inhibited cell invasion/migration through Matrigel extracellular matrix components at $24 \mathrm{~h}$ by $\sim 60 \%$. The addition of exogenous prostaglandin $\mathrm{E}_{2}$ partially attenuated the inhibition of cell invasion by $10 \mu \mathrm{M}$ NS-398, but failed to reverse the effect of I $00 \mu \mathrm{M}$ NS-398. Matrix metalloproteinases-2 (MMP-2) and -9 (MMP-9) are two enzymes that facilitate cell invasion/migration by degrading the extracellular matrix. In the presence of $100 \mu \mathrm{M}$ NS-398, Western blot hybridisation analysis and zymography demonstrated that both MMP-2 and MMP-9 protein levels and enzyme activity were decreased by $\sim 25-30 \%$. In separate studies, NS-398 also inhibited tumour growth in vivo and retarded the formation of liver metastasis. The results of these studies indicate that the expression and activity of COX-2 appear to be associated with both the proliferative and invasive properties of CRC. Cyclooxygenase-2 inhibition suppresses tumour cell growth and invasion/migration, and retards liver metastasis in a mouse colon cancer model, via multiple cellular and molecular mechanisms.

British Journal of Cancer (2004) 90, 712-719. doi:10.1038/sj.bjc.6601489 www.bjcancer.com

(c) 2004 Cancer Research UK

Keywords: colorectal cancer; COX-2 inhibition; invasiveness; metastasis

\begin{abstract}
Despite significant improvements in its prognosis due to advances in diagnosis and therapy modalities, colorectal cancer (CRC) remains second only to lung cancer as a cause of death from malignant disease in the United States (Landis et al, 1998; Brenner, 2002; Singh et al, 2002). Epidemiological studies have demonstrated a $40-50 \%$ reduction in mortality from CRC in individuals taking nonsteroidal anti-inflammatory drugs (NSAIDs) (Martinez et al, 1995; Ritland et al, 1999; Smalley et al, 1999; GarciaRodriguez and Huerta-Alvarez, 2001). These agents appear to reduce the risk of $\mathrm{CRC}$ by inhibiting cyclooxygenase (COX), also known as prostaglandin $\mathrm{G} / \mathrm{H}$ synthase (PGHS), a key enzyme involved in the conversion of arachidonic acid to tissue-specific prostaglandins. Two COX isoforms of cyclooxygenase (COX-1 and COX-2) have been identified, and both isoenzymes are regulated in a different manner and exhibit distinctive functional differences. Cyclooxygenase- 1 is expressed constitutively in many cell types, whereas COX-2 is a primary response gene whose expression may be induced by trauma, growth factors, tumour promoters and cytokines (Taketo, 1998a,b; Dannenberg and Zakim, 1999; Williams et al, 1999). Cyclooxygenase-2 was first discovered as
\end{abstract}

*Correspondence: Dr MM Wolfe; E-mail: michael.wolfe@bmc.org Received 29 August 2003; revised 5 September 2003; accepted 6 October 2003 an oncogene-responsive isoenzyme, and increased COX-2 expression has been found in up to $85 \%$ of colorectal adenocarcinomas, while it is undetectable in normal intestinal mucosa (Giardiello et al, 1995; Kargman et al, 1995).

Nonselective COX inhibitors, which inhibit both isoforms, have been reported to prevent tumorigenesis (Peura, 2002; Schwartz et al, 2002). However, the use of nonselective COX inhibitors is often associated with gastrointerestinal (GI) adverse events, whereas COX-2 selective inhibitors are thought to exert antiinflammatory and their antineoplastic properties with diminished toxicity (Hirata et al, 1997; Wolfe, 1998; Wolfe et al, 1999; Lichtenstein and Wolfe, 2000). NS-398, N-[2-(cyclohexyloxy)-4nitrophenyl]-methanesulphonamide, is a sulphonamide derivative that inhibits COX-2 specifically, with an $\mathrm{IC}_{50}$ of $30 \mathrm{~nm}$. This agent does not affect COX-1 activity at concentrations exceeding $100 \mu \mathrm{M}$, and it inhibits COX-1 prostanoid production only minimally, even at a dose exceeding $200 \mathrm{mg} \mathrm{kg}^{-1}$ (Futaki et al, 1994; Gierse et al, 1995). NS-398 can inhibit either chemically induced tumorigenesis in the colon or human cancer xenograft in nude mice (Yoshimi et al, 1997, 1999; Sawaoka et al, 1998).

NASIDs appear to exert their beneficial effects via multiple mechanisms in cancer chemoprevention. It has been generally assumed that the antiproliferative effects of NASIDs are dependent upon inhibition of COX activity and prostaglandin synthesis. The effects of COX-2 inhibitors on colonic carcinogenesis, cell cycle 
control, differentiation, angiogenesis and apoptosis in cancer chemopreventation have been described in numerous studies (Tsujii and DuBois, 1995; Tsujii et al, 1998). Relatively little attention has been given to COX with relation to tumour cell invasive potential and metastasis. We have recently reported that the COX-2 selective inhibitor rofecoxib decreased cell growth by several mechanisms and decreased the metastatic potential of CRC in the mouse (Yao et al, 2003). The mechanisms by which selective COX-2 inhibition inhibits metastasis have not been determined. The present studies were designed to extend our previous studies to determine whether selective COX-2 inhibition with NS-398 likewise reduces CRC tumour cell proliferation and invasion/ migration, and to elucidate the possible cellular and molecular mechanisms involved. The results of these studies indicate that the expression and activity of COX-2 appears to be associated with both the proliferative and invasive properties of CRC. Cyclooxygenase-2 inhibition significantly inhibits CRC growth and invasion/migration, and retards the formation of liver metastasis by multiple cellular and molecular mechanisms.

\section{MATERIALS AND METHODS}

\section{Cell culture}

The transplantable mouse CRC cell line MC-26 (Singh et al, 1986; Walker et al, 1986) was obtained from Dr KK Tanabe (Massachusetts General Hospital, Boston, MA, USA). MC-26 cells were maintained in Dulbecco's modified Eagle's medium (DMEM; Life Technologies, Inc, Gaithersburg, MD, USA) supplemented with $10 \%$ foetal calf serum plus antibiotics at $37^{\circ} \mathrm{C}$ in a humidified atmosphere of $95 \%$ air $/ 5 \% \mathrm{CO}_{2}$.

\section{Cell proliferation}

Cell proliferation was determined by DNA synthesis, and then confirmed by cell number counting. Cells $\left(10^{4} \mathrm{ml}^{-1}\right)$ were seeded onto 12 -well plates for $24 \mathrm{~h}$, followed by the addition of different concentrations of NS-398 (Cayman chemical, Ann Arbor, MI, USA). NS-398 was dissolved in dimethylsulphoxide (DMSO) as a stock solution. DNA synthesis was estimated by $\left[{ }^{3} \mathrm{H}\right]$-thymidine incorporation into cellular DNA. $\left[{ }^{3} \mathrm{H}\right]$-thymidine $1 \mu \mathrm{Ci} \mathrm{ml}^{-1}$ (New England Nuclear Products, Boston, MA, USA) was added and allowed to label for $6 \mathrm{~h}$ at $37^{\circ} \mathrm{C}$. Cells were washed $\times 3$ with cold phosphate-buffered saline (PBS), and cold $10 \%$ trichloroacetic acid (TCA) was added to cells for $30 \mathrm{~min}$ at $4^{\circ} \mathrm{C}$. Cells were washed again $\times 3$ with cold PBS, after which they were lysed in $0.1 \mathrm{~N}$ $\mathrm{NaOH} / 10 \%$ SDS and radioactivity measured in a liquid scintillation counter. Data were expressed as the percentage of control, in order to reduce variation among separate experiments. Protein synthesis was measured by a BCA protein assay kit (Pierce chemical, Rockford, IL, USA), according to the protocol provided by the manufacturer. For cell number counting, cells $\left(10^{4} \mathrm{ml}^{-1}\right)$ were seeded onto six-well plates for $24 \mathrm{~h}$, followed by the addition of different concentrations of NS-398. Cells were harvested and then cell numbers were manually counted under the microscope.

\section{Prostaglandin $\mathrm{E}_{2}$ assay}

Prostaglandin $\mathrm{E}_{2}\left(\mathrm{PGE}_{2}\right)$, the major metabolite of arachidonic acid metabolism, was measured by ELISA (Cayman Chemical, Ann Arbor, MI, USA) with conditional cell culture medium, according to the protocol provided by the manufacturer. Measurements were made in triplicate in separate experiments.

\section{Cell invasion/migration assay}

A membrane invasion culture system (Collaborative Biomedical Products, Bedford, MA, USA) was used to quantify cell invasion and migration, as described previously (Rozic et al, 2001). The upper surface of the polycarbonate filter with $8-\mu \mathrm{m}$ pores was coated with Matrigel, and placed between the upper and lower well plates of the membrane invasion system. Serum-free Swiss 3T3 fibroblast conditional medium (CM) was prepared by incubation of these cells for $24 \mathrm{~h}$. This medium was used as a chemoattractant in the lower chamber. After reaching 60-70\% subconfluence, cells were harvested by trypsinisation and suspended in DMEM, and harvested cells $\left(10000 \mathrm{ml}^{-1}\right)$ were seeded into the upper chambers. Cells were cultured in the presence of various concentrations of NS-398 alone, or in combination with exogenous PGE $_{2}$ (Cayman Chemical, Ann Arbor, MI, USA) for $24 \mathrm{~h}$. At the end of 24 incubation at $37^{\circ} \mathrm{C}$, the cells in the upper surface of the Matrigelcoated filter were mechanically removed, the filters fixed with methanol, stained with haematoxylin and eosin, and the cells on the lower surface were counted manually.

\section{Gelatin zymography}

Gelatin zymography was performed using CM harvested from MC26 cells under various conditions as described (Nomura et al, 1995; Liabakk et al, 1996). Conditional medium was collected and concentrated six-fold using Centricon 10 filter (Amicon), and then subjected to $10 \%$ SDS - PAGE with $1 \mathrm{mg} \mathrm{ml}^{-1}$ gelatin incorporated into the gel mixture. Following electrophoresis at $4{ }^{\circ} \mathrm{C}$, the gel was soaked in $2.5 \%$ Triton X-100 to remove the SDS, rinsed in $\mathrm{H}_{2} \mathrm{O}$ $\times 3$, and then transferred to a developing buffer ( $50 \mathrm{~mm}$ Tris-HCL pH 7.5, $\left.5 \mathrm{~mm} \mathrm{CaCl}_{2}, 200 \mathrm{~mm} \mathrm{NaCl}\right)$ at $37^{\circ} \mathrm{C}$ overnight. Gels were stained with Coomassie blue for $2-3 \mathrm{~h}$ and then destained with $30 \%$ methanol and $10 \%$ acetic acid. The unstained bands (digested gelatin) correspond to the presence of matrix metalloproteinase (MMP) proteolytic activity.

\section{Animal experimental design}

Male BALB/c mice, 6-week old, were obtained from Taconic (Germantown, NY, USA). The mouse colon cancer model was established as described previously (Yao et al, 2002). MC-26 cells were harvested from subconfluent cultures by exposure to trypsinEDTA (Life Technologies, Inc, Gaithersburg, MD, USA) for $3 \mathrm{~min}$, centrifugation at $300 \mathrm{~g}$ for $15 \mathrm{~min}$ at room temperature, and then resuspension in serum-free DMEM or Hank's balanced salt solution (Life Technologies, Inc, Gaithersburg, MD, USA), to yield a final concentration of $10^{5}$ cells $\mathrm{ml}^{-1}$. Using a 27 -gauge needle and a $1-\mathrm{ml}$ syringe, $100 \mu \mathrm{l}$ of tumour cell suspension was injected subcutaneously into the flank of the mice. All animal studies were conducted using a protocol approved by the Institutional Animal Care and Use Committee of Boston University Medical Center.

NS-398, dissolved in DMSO, was administered by oral gavage once daily. Mice were randomly divided into three groups (10 animals/group) on day 0 after tumour cell implantation: vehicle (DMSO), NS-398 $1 \mathrm{mg} \mathrm{kg}^{-1}$, NS-398 $10 \mathrm{mg} \mathrm{kg}^{-1}$. Starting on day 7, subcutaneous tumour size was determined by measuring the longest and shortest diameters of the tumour at 2-3 days intervals. Tumour volume $\left(\mathrm{mm}^{3}\right)$ was calculated by a standard formula: volume $=(\text { the shortest diameter })^{2} \times($ the longest diameter $) \times 0.5$. Tumour weight was also measured on day 18 after tumours were removed from the killed mice. Tumour tissue was frozen in liquid nitrogen and stored at $-70^{\circ} \mathrm{C}$.

For the liver metastasis tumour model, $2 \times 10^{4}$ cells ml $^{-1} \mathrm{MC}-26$ cells were injected into the subsplenic capsule of 6 -10-week-old $\mathrm{BALB} / \mathrm{c}$ mice under intraperitoneal anaesthesia using pentobarbital (65 mg kg ${ }^{-1}$ body weight) on day 0 . After full recovery from surgery, mice were randomly divided into three groups $(n=12$ per group): vehicle (DMSO), NS-398 $10 \mathrm{mg} \mathrm{kg}^{-1}$, and NS-398 $100 \mathrm{mg} \mathrm{kg}^{-1}$. Mice were administered with NS-398 once a day by gavage, starting on day 1 . Six mice in each group were killed on 
day 10 and another six mice on day 14 . The incident rates of liver metastases were recorded.

\section{Western blot hybridisation}

Mouse cyclin D1 and COX-2 monoclonal antibodies were purchased from $\mathrm{BD}$ transduction laboratories (Lexington, KY, USA). To extract the protein, MC 26 cells were harvested and lysed in RIPA buffer (PBS, $1 \%$ NP-40, $0.5 \%$ sodium deoxycholate, $0.1 \%$ SDS, $100 \mathrm{ng} \mathrm{ml}^{-1} \mathrm{PMSF}, 66 \mathrm{ng} \mathrm{ml}^{-1}$ aprotinin). To extract protein from tissues, $0.1 \mathrm{~g}$ tumour tissue was put in $2.0 \mathrm{ml}$ of cold protein extract buffer (RIPA buffer) and homogenised for $1 \mathrm{~min}$ with Polytron-Aggregate (Kinmatica, Luzern, Switzerland). After the removal of cellular debris by centrifugation, total protein extracted from cells or tissues was determined by BCA protein assay (Pierce chemical, Rockford, IL, USA). Protein was mixed with gel-loading buffer ( $50 \mathrm{~mm}$ Tris $\mathrm{pH} 6.8,2 \%$ SDS, $10 \%$ glycerol, $2 \%$ 2-mercaptoethanol, $0.1 \%$ bromphenol blue) and heated for $10 \mathrm{~min}$ at $100^{\circ} \mathrm{C}$. Samples containing 5-20 $\mu \mathrm{g}$ protein were loaded onto $10-12 \%$ SDS-PAGE gel, and then electrophoretically transferred to polyvinylidene difluoride membrane in a transfer buffer (25 mm Tris, $190 \mathrm{~mm}$ glycine, $20 \%$ methanol). The blots were blocked with $7 \%$ dry milk for $1 \mathrm{~h}$ at room temperature and incubated with the first antibody overnight. The blots were then washed three times for $15 \mathrm{~min}$ each in Trisbuffered saline containing $0.05 \%$ tween-20. The blots were further incubated with the anti-mouse IgG antibody (Sigma Chemical Co., St Louis, MO, USA) for $1 \mathrm{~h}$ at room temperature. After washing three times, blots were incubated with luminous ECL reagent (Pierce chemical, Rockford, IL, USA) for 10-120 s and exposed to Kodak X-ray film. Protein bands were identified by protein size and positive control provided by $\mathrm{BD}$ transduction laboratories (Lexington, KY, USA). The amount of protein expression was quantified by densitometry.

\section{Immunohistochemistry}

Proliferating cell nuclear antigen (PCNA) monocolonal antibodies were purchased from BD transduction laboratories. Paraffinembedded specimens were deparaffinised and incubated with PCNA antibody for $2 \mathrm{~h}$ at $37^{\circ} \mathrm{C}$. The specimens were then incubated with secondary antibody, anti-mouse IgG, for $1 \mathrm{~h}$ at $37^{\circ} \mathrm{C}$, and stained by the avidin-biotin peroxide complex (ABC) method using an ABC staining system (Santa Cruz Biotech, Santa Cruz, CA, USA). They were visualised by $3,3^{\prime}$-diaminobenzidine (DAB) and counterstained with haematoxylin. To confirm the specificity of the mouse PCNA antibody, human tonsil specimens was used as a positive control. The PCNA index was evaluated by counting the number of PCNA-positive-staining cells per 500 tumour cells: PCNA index $=$ (numbers of PCNA-positive-staining cells/500 cells counted) $\times 100 \%$.

\section{Statistical analysis}

One-way ANOVA was performed for comparing the tumour volume and weight, PCNA index and densitometric values of Western blot bands among different animal groups, followed by Tukey's procedure for pairwise comparison. Incident rates of liver metastatsis were analysed using the Fisher's exact test. Statistical significance was assigned if $P<0.05$.

\section{RESULTS}

\section{COX-2 expression and prostaglandin levels following treatment with NS-398}

Although NS-398 has been shown to decrease the activity of COX-2 in some CRC cell lines, no significant changes in COX-2 protein expression were detected in mouse colorectal adenocarcinoma cell line MC-26 after treatment with NS-398 $(1,10$ and $100 \mu \mathrm{M})$ for $24 \mathrm{~h}$ (Figure 1A). In contrast, concentration-dependent decreases in $\mathrm{PGE}_{2}$, a major product of the arachidonic acid pathway, were demonstrated after $24 \mathrm{~h}$ of incubation with NS-398. Compared with vehicle incubation $\left(2.08 \pm 0.35 \mathrm{ng} \mathrm{mg}^{-1}\right.$ total protein $), \mathrm{PGE}_{2}$ content in cells treated with 1,10 and $100 \mu \mathrm{M}$ NS-398 were diminished by approximately $50 \% \quad\left(1.00 \pm 0.20 \mathrm{ng} \mathrm{mg}^{-1}\right), \quad 80 \%$ $\left(0.48 \pm 0.03 \mathrm{ng} \mathrm{mg}^{-1}\right)$ and $90 \%\left(0.25 \pm 0.07 \mathrm{ng} \mathrm{mg}^{-1}\right)$, respectively (Figure 1B).

\section{Cell proliferation and tumour growth in vivo}

The addition of NS-398 to MC-26 cells led to a concentrationdependent decrease in $\left[{ }^{3} \mathrm{H}\right]$-thymidine incorporation. NS-398 1, 10 and $100 \mu \mathrm{m}$ decreased cell proliferation to $84.3,57.2$ and $34.6 \%$ at $72 \mathrm{~h}$, respectively, compared to cells incubated in the absence of NS-398 (Figure 2A). These results had been confirmed by cell number counting, showing that significant cell number reduction occurred at $72 \mathrm{~h}$ after NS-398 treatment (Figure 2B). Figures 3A and B depict the effects of NS-398 on subcutaneous tumour volume and tumour weight at the end of the study (day 18). Although low-dose $\left(1 \mathrm{mg} \mathrm{kg}^{-1}\right)$ NS-398 did not affect subcutaneous tumour growth compared with control animals (tumour volume: $1208.2 \pm 223.6$ vs $1220.2 \pm 224.0 \mathrm{~mm}^{3}$; tumour weight: $0.392 \pm 0.08$ vs $0.384 \pm 0.07 \mathrm{~g}, P>0.05)$, high-dose $\left(10 \mathrm{mg} \mathrm{kg}^{-1}\right)$ NS-398 significantly decreased subcutaneous tumour growth (tumour volume: $843.3 \pm 226.8 \mathrm{~mm}^{3}$; tumour weight: $0.218 \pm 0.05 \mathrm{~g}$, both $P<0.05)$. As shown in Figure 3C, no significant changes in body weight were detected among these groups.

\section{A}

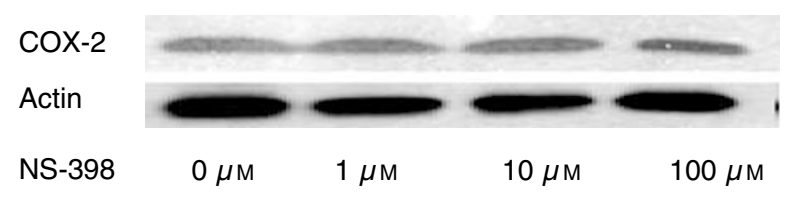

B

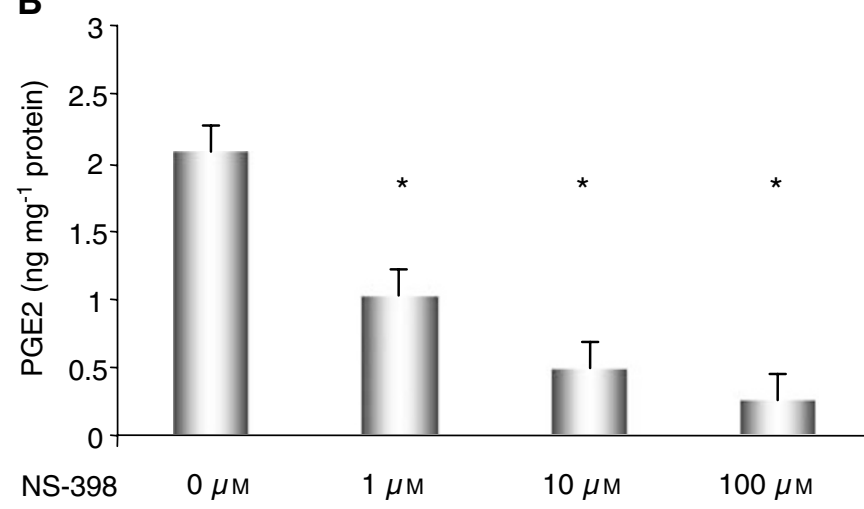

Figure I (A) Western blot of COX-2 protein and (B) quantification of its product, $\mathrm{PGE}_{2}$. MC-26 cells were maintained in DMEM media supplemented with $10 \%$ foetal calf serum. Cells $\left(100000 \mathrm{ml}^{-1}\right)$ were seeded for $24 \mathrm{~h}$, followed by the addition of different concentrations of NS398. Total protein was extracted and Western blot hybridisation performed for COX-2 expression. PGE 2 was measured using ELISA, as described in Materials and methods section. Measurements were made in triplicate in three separate experiments, and data are depicted as the mean \pm standard error (s.e.). ${ }^{*} P<0.0 \mathrm{I}$, compared to control (vehicle). 
A

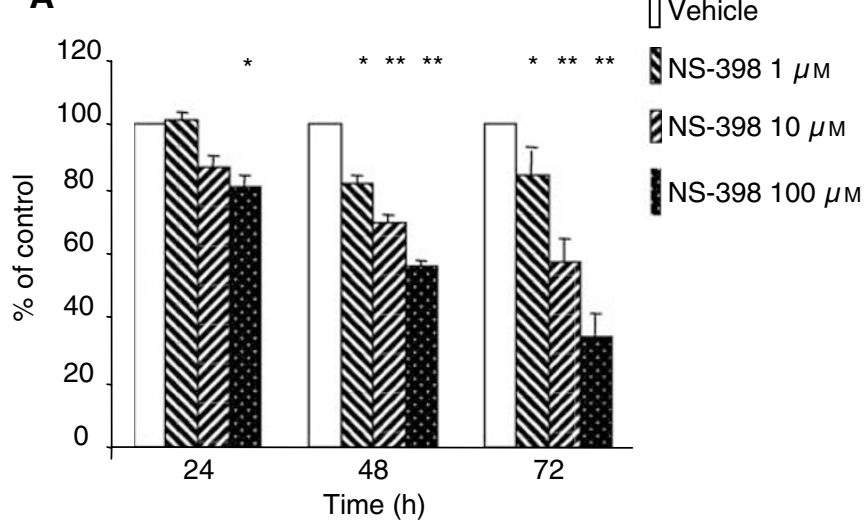

B

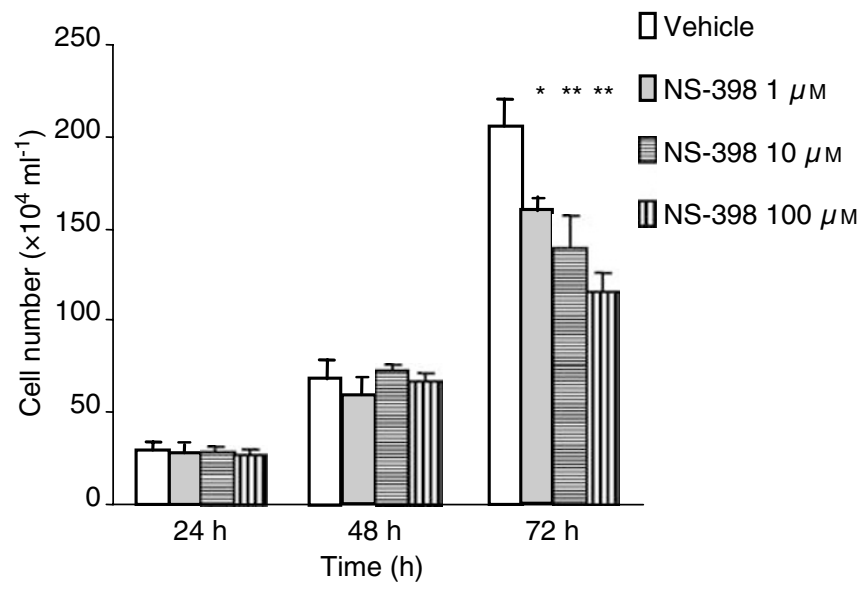

Figure 2 Effect of NS-398 on cellular proliferation. (A) DNA synthesis was measured by $\left.{ }^{3} \mathrm{H}\right]$-thymidine incorporation into cellular DNA. $\left.{ }^{3} \mathrm{H}\right]$ thymidine $\mid \mu \mathrm{Ci} \mathrm{ml}^{-1}$ was added and allowed to label for $6 \mathrm{~h}$ at $37^{\circ} \mathrm{C}$. Cell lysates were analysed in a liquid scintillation counter. Data are expressed as the percentage of control (vehicle) \pm s.e. (B) Cells $\left(10^{4} \mathrm{ml}^{-1}\right.$ ) were seeded onto six-well plates for $24 \mathrm{~h}$, followed by the addition of different concentrations of NS-398. Cells were harvested and then cell numbers were manually counted under the microscope. $* P<0.05$, ${ }^{*} * P<0.01$, compared to control (vehicle).

To further assess the inhibitory effects of NS-398 on cell proliferation and tumour growth, we measured cyclin $D_{1}$ and PCNA levels using Western blot hybridisation and immunohistochemistry. Cyclin $\mathrm{D}_{1}$ is one of the key proteins involved in cell cycle regulation in normal cells (Hunter and Pines, 1994; Sherr, 1996). In the $G_{1}$ (resting) phase of the cell cycle, cyclin $D_{1}$ along with its cyclin-dependent kinase (CDK) partner, is responsible for transition to the $\mathrm{S}$ (DNA synthesis) phase. Overexpression of cyclin $\mathrm{D}_{1}$ releases a cell from its normal control and causes transformation to a malignant phenotype (Motokura and Arnold, 1993; Bartkova et al, 1994; Arber et al, 1996; Sutter et al, 1997). PCNA functions as an auxiliary protein to DNA polymerase- $\gamma$ and as a co-factor in DNA synthesis. The determination of PCNA represents one of the most reliable methods for evaluating proliferation in cells and tissues (Prosperi, 1997). In the present study, consistent with the cell proliferation and tumour growth, cyclin $\mathrm{D}_{1}$ levels (normalised to actin protein) were decreased after MC-26 cells were incubated in the presence of NS-398 $(100 \mu \mathrm{M})$ for 48 and $72 \mathrm{~h}$ (Figure 4A). The PCNA index was also significantly decreased in mice treated with NS-398 $10 \mathrm{mg} \mathrm{kg}^{-1}$, compared with mice administered vehicle only $(27.0 \pm 3.2$ vs $10.8 \pm 2.6 \%, P<0.01)$ (Figure 4B, C).

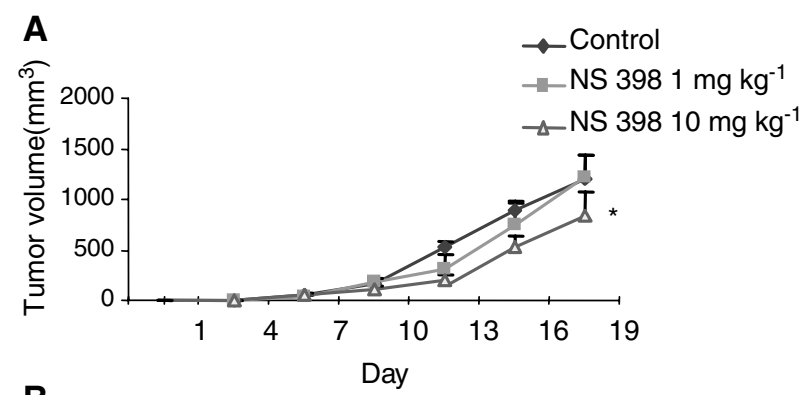

B
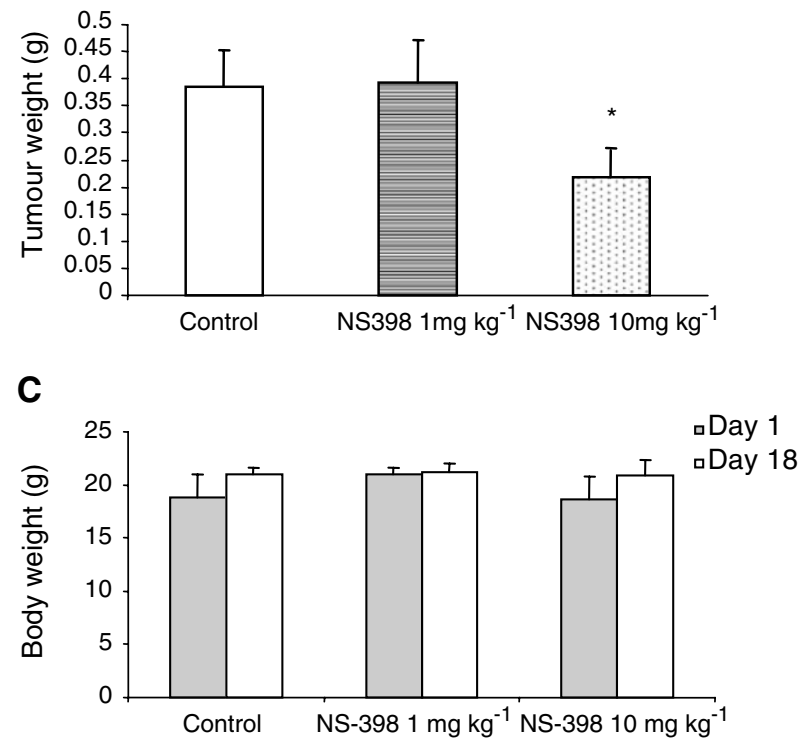

Figure 3 (A) Tumour growth (volume) in vivo over time and (B) tumour weight and (C) body weight after excision on day 18. Tumour volume $\left(\mathrm{mm}^{3}\right)$ was determined by measuring the longest and shortest diameter of the tumour, and was calculated by a standard formula: volume $=(\text { the shortest diameter })^{2} \times($ the longest diameter $) \times 0.5$. Tumour weight was measured on day 18, after excision from the killed mice. Data are expressed as the mean \pm s.e. $* P<0.05$, compared to control (vehicle).

\section{Effects of NS-398 on cell invasion potential and liver metastasis}

To quantify cell invasion, we employed a Matrigel invasion chamber assay. Matrigel is a solubilised basement membrane preparation containing extracellular components such as laminin, collagen type IV, heparin sulphate proteoglycan, and growth factors such as TGF and basic FGF. The layer of Matrigel Matrix simulates a reconstituted basement membrane in vitro. To perform these experiments, an invasion assay was established, that included upper and lower chambers separated by a filter, onto which the cells are trapped and can be counted. The bottom of the upper chamber was coated with Matrigel. Highly invasive cells are able to degrade the extracellular matrix components and migrate through the layer of Matrigel to the other side of filter by activating various proteinases. The lower chamber was filled with serum-free conditioned 3T3 fibroblast medium, to act as a chemoattractant. Cells pretreated with NS-398 or vehicle were loaded into the upper chamber, and, following a 24 -h incubation period, the number of cells attached to the filters below the Matrigel layer was counted. As shown in Figure 5, 1-100 $\mu \mathrm{m}$ NS-398 inhibited cell invasion/ migration through the Matrigel extracellular matrix components at $24 \mathrm{~h}$ in a concentration-dependent reduction, with maximum inhibition of $78 \%$ of control $(13.0 \pm 5.4$ vs $58.5 \pm 13.1$ cells per microscopic field under control conditions, $P<0.01)$. Since cell 
A

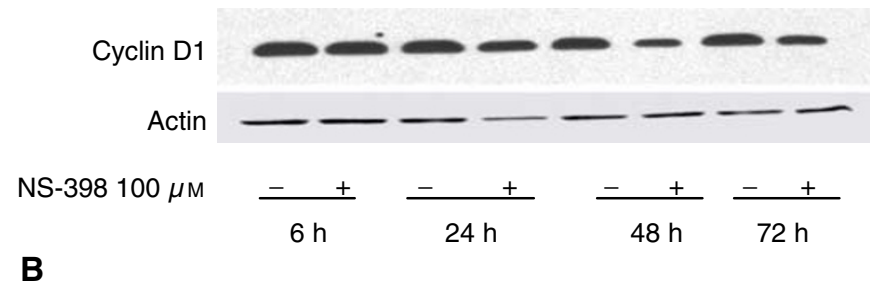

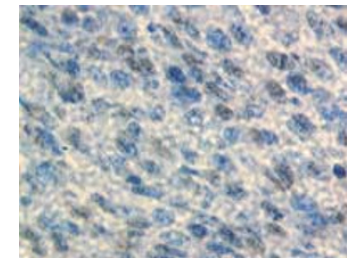

Control

C

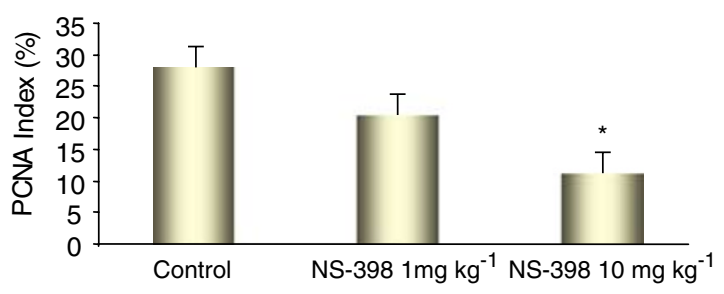

Figure 4 (A) Effect of NS-398 on cyclin DI protein expression in cells over time, (B) representative photomicrograph of PCNA staining of tumour tissue, and (C) PCNA index. Cyclin DI protein was detected by Western blot hybridisation, and PCNA was determined by immunohistochemistry. PCNA index was calculated by counting the number of PCNA-positive-staining cells per 500 tumour cells: PCNA index $=$ (numbers of PCNA-positive cells/500 cells counted) $\times 100$ $* P<0.05$, compared to control.

number did not significantly decrease at $24 \mathrm{~h}$ after NS-398 treatment (Figure 5), the inhibitory effect of NS-398 at $24 \mathrm{~h}$ may occur as a result of reduced cell-invasive capacity rather than a reduction in cell number. The addition of exogenous $\mathrm{PGE}_{2}$ partially attenuated the inhibition of cell invasion produced by $10 \mu \mathrm{m}$ NS-398, but not in cells treated with $100 \mu \mathrm{M}$ NS-398.

To further explore the molecular mechanisms by which NS-398 decreased the invasive capacity of MC-26 cells, we measured MMP concentrations. Metalloproteinases consist of a family of nine or more highly homologous $\mathrm{Zn}^{2+}$ peptidases that collectively cleave the constituents of extracellular matrix and facilitate tumour cell invasion and migration. Metalloproteinases play an important role in tumour invasion and metastasis (Curran and Murray, 2000; Nelson et al, 2000). Within the MMP family, MMP-2 and -9, also called gelatinases or type-IV collagenases, have been implicated to play a significant proteolytic role in CRC invasion and metastasis. As seen in Figure 6, after the incubation of MC-26 cells with $100 \mu \mathrm{M}$ NS-398 for $24 \mathrm{~h}$, both protein expression (Western blot) and enzyme activity (zymography) of MMP-2 and -9 enzymes were decreased by approximately $25-30 \%(P<0.05)$.

The liver is the major target organ for CRC metastasis. We established a CRC liver metastasis model by injecting tumour cells into the splenic subcapsule. Visible metastatic lesions in the liver were detected by day 7 after cell inoculation. On day 10, the incidence of liver metastasis in the NS-398-treated group $\left(100 \mathrm{mg} \mathrm{kg}^{-1} \mathrm{day}^{-1}\right)$ was significantly lesser than that in control group (one out of six $v s$ five out of six, $P<0.05$ ). However, on day 14 , liver metastasis occurred in $100 \%$ (six out of six) in control and $83.33 \%$ (five out of six) in the NS-398-treated group (NS-398
A

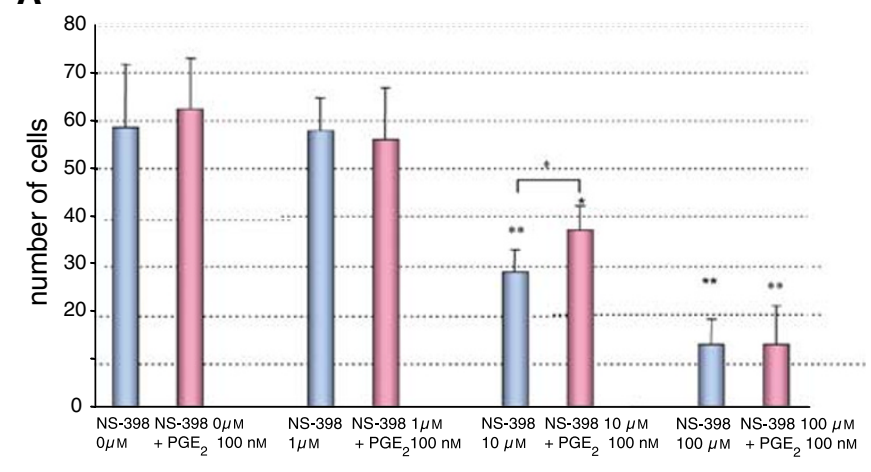

B
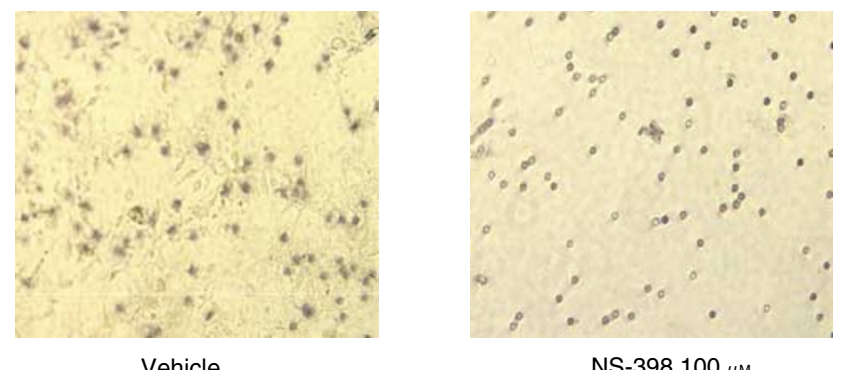

NS-398 $100 \mu \mathrm{m}$
Figure 5 Effect of NS-398 on cell invasion/migration in vitro. Cell invasion/migration assay was performed using the Matrigel invasive chamber system, as described in Materials and methods section. (A) Number of cells on the undersurface of filters after $24 \mathrm{~h}$ in the presence of NS-398 alone, or in combination with PGE2 100 nM. (B) Representative photomicrograph of cells on the undersurface of filters after $24 \mathrm{~h}$ in the presence of NS-398 I00 $\mu$ M or vehicle. $* P<0.05$, $* * P<0.01$, compared to NS-398 $0 \mu \mathrm{M}$.

$\left.100 \mathrm{mg} \mathrm{kg}^{-1} \mathrm{day}^{-1}, P>0.05\right)$. These results indicate that NS-398 delayed, but did not prevent, liver metastasis (Figure 7).

\section{DISCUSSION}

COX-2 overexpression has been demonstrated in $\sim 85 \%$ of cases of primary CRC. Overexpression of COX-2 appears to alter the phenotype of intestinal epithelial cells and increases their carcinogenic potential. A number of epidemiological studies have shown that the prolonged use of aspirin and other nonsteroidal anti-inflammatory drugs (NSAIDs) can reduce the relative risk of CRC (Giovannucci et al, 1994; Smalley et al, 1999). For example, a recent population-based survey in $>100000$ individuals 65 years of age and older found that the long-term use of NSAIDs diminished the risk of CRC by $\sim 50 \%$ (Giovannucci et al, 1994; Smalley et al, 1999). Another large population-based survey reported that the use of NSAIDs significantly reduced the risk of both gastric and oesophageal carcinoma (Farrow et al, 1998). Although the precise mechanisms by which NSAIDs, and COX-2 selective inhibitors in particular, modulate tumour growth have not been elucidated, it appears that cell cycle arrest and apoptosis may play a critical role (Chang and Weng, 2001; Grosch et al, 2001; Cheng et al, 2002; Joe et al, 2002; Kundu et al, 2002; Toyoshima et al, 2002). Alternatively, Sawaoka et al (1998) and Tsujii et al (Tsujii and DuBois, 1995; Sawaoka et al, 1998; Tsujii et al, 1998) have suggested that a decrease in angiogenesis may account for the inhibitory properties of COX-2 selective NSAIDs on tumour growth. Early studies demonstrated that sulindac was effective in 


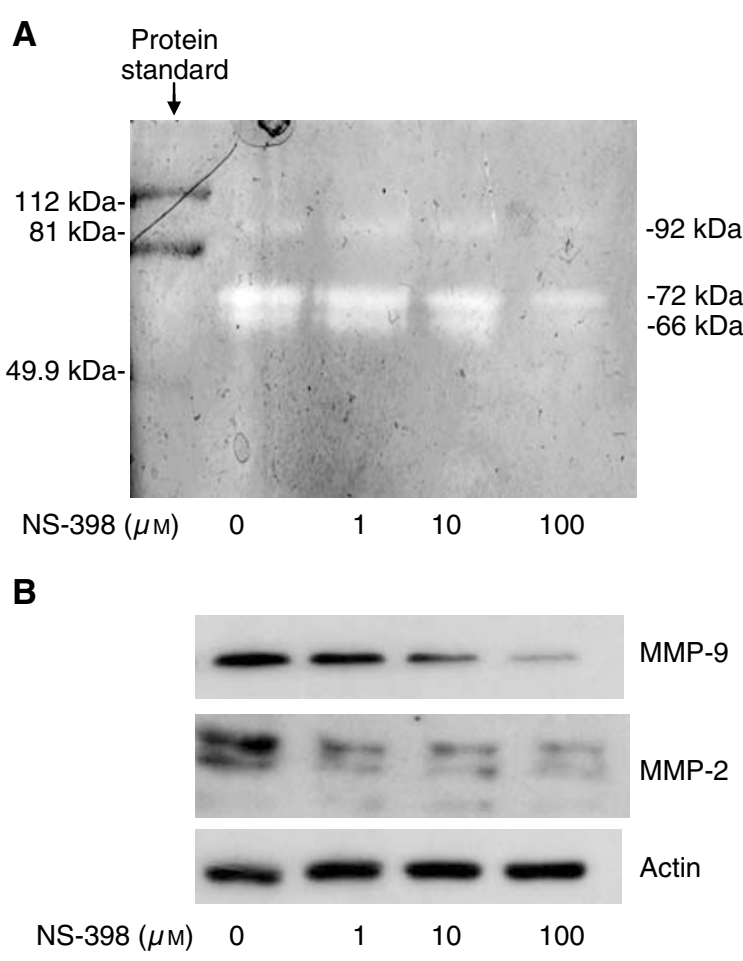

Figure 6 (A) Activity of MMP-2 and -9 in NS-398-treated cells using gelatin zymography and (B) protein expression of MMP-2 and -9 using Western blot hybridisation, as described in Materials and methods section. MC-26 cells were cultured without and with increasing concentrations of NS-398 for $24 \mathrm{~h}$.

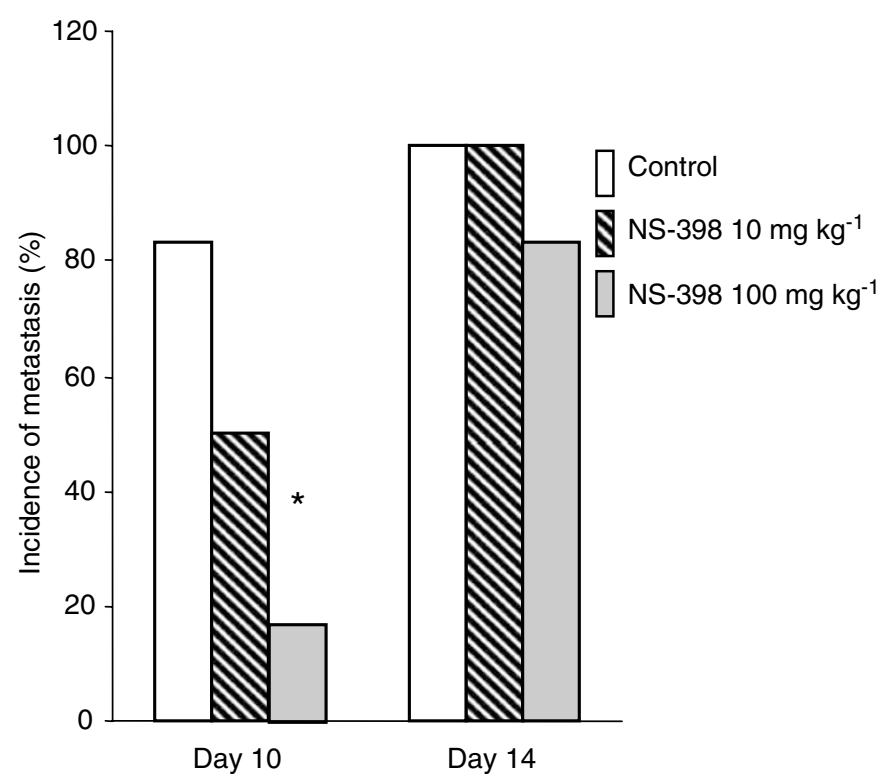

Figure 7 Effect of NS-398 on liver metastasis. A mouse CRC liver metastasis model was established by splenic subcapsule tumour cell injection. Mice were administered vehicle or NS-398 (10 or $100 \mathrm{mg} \mathrm{kg}^{-1}$ ) once daily by gavage. On days 10 and 14 , the incidence of liver metastasis was recorded. $* P<0.05$, compared to control.

reducing the number of colonic polyps in individuals with familial adenomatous polyposis (FAP), presumably by decreasing the activity of COX (Waddell and Loughry, 1983). Selective COX-2 inhibitors share the antitumour properties of nonselective NSAIDs like sulindac, but are associated with far fewer adverse GI events (Wolfe, 1998; Wolfe et al, 1999). Cyclooxygenase-2 selective inhibitors have been shown to inhibit the growth of tumour cells in vitro (Sheng et al, 1997). They also reduce the development of precancerous adenomatous polyps in the $A p c^{\Delta 716}$ knockout mouse, a model of human hereditary familial adenomatous polyposis, and in the azoxymethane rat model, which produces benign and malignant colorectal adenomatous polyps analogous to nonhereditary spontaneous development of colorectal adenocarcinoma (Williamson et al, 1978; Oshima et al, 1996; Singh et al, 2000).

In December 1999, the US Food and Drug Administration approved the use of the COX-2 selective NSAID celecoxib in individuals with FAP, both for the regression and reduction of polyps. While FAP serves as an excellent model for CRC, it is a rare condition, accounting for $<1 \%$ of all cases. The present therapy for the treatment of advanced CRC is not only quite toxic, but also largely ineffective. A previous in vitro study using cell lines of CRC origin by Tsujii et al (1997) suggested that COX-2 inhibition may be beneficial in preventing the expression of genes associated with metastatic progression. Furthermore, a recent study by Tomozawa et al (1999) demonstrated that the COX-2 selective inhibitor JTE522 might decrease the rate of haematogenous metastasis of CRC.

Many NSAIDs have been found to inhibit cell division and alter cell cycle distribution in culture colon cancer cells (Xu et al, 1999; Grosch et al, 2001; Kundu et al, 2002). In the present study, cell proliferation was inhibited by NS-398, a COX-2 selective inhibitor, in a concentration-dependent manner, with a maximum inhibition of $34.6 \%$ of control values. In the subcutaneous colon tumour models, mice treated with $10 \mathrm{mg} \mathrm{kg}^{-1} \mathrm{NS}-398$ displayed approximately $50-70 \%$ of the tumour burden compared to control animals. To confirm the antiproliferative effect of NS-398, we examined two proliferation-related molecules: cyclin D1 and PCNA. Previous studies have demonstrated that cyclin D1 is increased in adenomatous polyps and in both sporadic and familial forms of CRC (Motokura and Arnold, 1993; Bartkova et al, 1994; Arber et al, 1996; Sutter et al, 1997). The synthesis and expression of PCNA are enhanced in proliferating cells, including those that are tumour-derived. Consistent with the cell proliferation and animal tumour growth data observed, cyclin D1 and PCNA index were significantly decreased by NS-398 both in vitro and in vivo.

Tumour metastasis is a complex multifactorial and multistep biological process. Tumour cell invasive potential, host microenviroment and interactions between host and tumour cells are among the factors influencing the establishment and development of metastatic lesions (Woodhouse et al, 1997). Cyclooxygenase-2 overexpression has been associated with increased adhesion to the extracellular matrix and the inhibition of apoptosis (Tsujii and DuBois, 1995). Cyclooxygenase-2 also leads to alterations in the invasive potential of CRC cells (Tsujii et al, 1997). Metastatic CRC cells from liver and primary CRC tissue exhibit much higher levels of COX-2 than the corresponding adjacent normal mucosa from the same patient. Among patients with relatively high COX-2 expression in the primary tumour, almost all were found to exhibit even higher levels of COX-2 in their hepatic metastases (Chen et al, 2001). The precise mechanism underlining the roles of COX-2 in the metastasis process is unknown. It has been reported that proteolysis of the extracellular matrix and angiogenesis are involved in the process (Tsujii and DuBois, 1995; Tsujii et al, 1997, 1998). One of the major steps in the process of cancer cell invasion is proteolysis of the extracellular matrix, especially the basement membrane, including fibronectin, laminin, type IV collagen and proteoglycans (Coussens et al, 2002; Vihinen and Kahari, 2002). Using reconstituted basement membrane Matrigel in vitro, we found that NS-398 significantly inhibited the capacity of cell invasion and migration through the extracellular matrix by inactivating the activities of MMP-2 and -9. Metalloproteinase inhibition could thus account for one of the molecular mechanisms 
involved in mediating the anti-invasive properties of NS-398. We also found that the addition of exogenous $\mathrm{PGE}_{2}$ partially attenuated the inhibition effect of NS-398 at $10 \mu \mathrm{M}$, but not with $100 \mu \mathrm{M}$, indicating that the invasion/migration-inhibitory effects of NS-398 might also be modulated through COX-independent pathways.

To determine whether NS-398 possessed any inhibitory effects on the development of liver metastasis, we utilised an animal model that generates metastasis by the injection of MC-26 cells into the splenic subcapsule. Although we did observe a decrease in subcutaneous tumour growth in response to the administration of $10 \mathrm{mg} \mathrm{kg}^{-1} \mathrm{NS}-398$ (Figure 3), this same dose had no significant effect on liver metastasis. When administered by gavage at a daily dose of $100 \mathrm{mg} \mathrm{kg}^{-1}$, however, the rate of metastasis was significantly diminished (Figure 7). The mechanisms accounting for the higher dose requirements are not known, but may be due, at least in part, to the more abundant blood supply in the spleen compared to the subcutaneous space or alternatively to differences in the cellular and molecular mechanisms responsible for mediating the effects of COX-2 inhibition on tumour growth and metastasis. NS-398 at the $100 \mathrm{mg} \mathrm{kg}^{-1}$ dose decreased the development of liver metastasis on day 10 , but not on day 14 , indicating that NS-398 appears to retard, but not prevent, the early formation of liver metastasis using this model.

In conclusion, the expression and activity of COX-2 appears to be associated with the proliferative and invasive properties of CRC. Cyclooxygenase inhibition suppresses tumour cell growth and invasion, and retards the formation of liver metastasis in a mouse CRC model by multiple cellular and molecular mechanisms. Further studies are warranted to evaluate the possibility that COX2 inhibition be considered as part of the treatment regimen for advanced CRC.

\section{REFERENCES}

Arber N, Hibshoosh H, Moss SF, Sutter T, Zhang Y, Begg M, Wang S, Weinstein IB, Holt PR (1996) Increased expression of cyclin D1 is an early event in multistage colorectal carcinogenesis. Gastroenterology 110: $669-674$

Bartkova J, Lukas J, Strauss M, Bartek J (1994) The PRAD-1/cyclin D1 oncogene product accumulates aberrantly in a subset of colorectal carcinomas. Int J Cancer 58: $568-573$

Brenner H (2002) Long-term survival rates of cancer patients achieved by the end of the 20th century: a period analysis. Lancet 360 : $1131-1135$

Chang HC, Weng CF (2001) Cyclooxygenase-2 level and culture conditions influence NS398-induced apoptosis and caspase activation in lung cancer cells. Oncol Rep 8: $1321-1325$

Chen WS, Wei SJ, Liu JM, Hsiao M, Kou-Lin J, Yang WK (2001) Tumor invasiveness and liver metastasis of colon cancer cells correlated with cyclooxygenase-2 (COX-2) expression and inhibited by a COX-2selective inhibitor, etodolac. Int J Cancer 91: 894-899

Cheng J, Imanishi H, Amuro Y, Hada T (2002) NS-398, a selective cyclooxygenase 2 inhibitor, inhibited cell growth and induced cell cycle arrest in human hepatocellular carcinoma cell lines. Int J Cancer 99: $755-761$

Coussens LM, Fingleton B, Matrisian LM (2002) Matrix metalloproteinase inhibitors and cancer: trials and tribulations. Science 295: $2387-2392$

Curran S, Murray GI (2000) Matrix metalloproteinases: molecular aspects of their roles in tumour invasion and metastasis. Eur J Cancer 36: $1621-1630$

Dannenberg AJ, Zakim D (1999) Chemoprevention of colorectal cancer through inhibition of cyclooxygenase-2. Semin Oncol 26: 499-504

Farrow DC, Vaughan TL, Hansten PD, Stanford JL, Risch HA, Gammon MD, Chow WH, Dubrow R, Ahsan H, Mayne ST, Schoenberg JB, West AB, Rotterdam H, Fraumeni Jr JF, Blot WJ (1998) Use of aspirin and other nonsteroidal anti-inflammatory drugs and risk of esophageal and gastric cancer. Cancer Epidemiol Biomarkers Prev 7: 97 - 102

Futaki N, Takahashi S, Yokoyama M, Arai I, Higuchi S, Otomo S (1994) NS398, a new anti-inflammatory agent, selectively inhibits prostaglandin G/ $\mathrm{H}$ synthase/cyclooxygenase (COX-2) activity in vitro. Prostaglandins 47: $55-59$

Garcia-Rodriguez LA, Huerta-Alvarez C (2001) Reduced risk of colorectal cancer among long-term users of aspirin and nonaspirin nonsteroidal antiinflammatory drugs. Epidemiology 12: 88-93

Giardiello FM, Offerhaus GJ, DuBois RN (1995) The role of nonsteroidal anti-inflammatory drugs in colorectal cancer prevention. Eur J Cancer 31A: $1071-1076$

Gierse JK, Hauser SD, Creely DP, Koboldt C, Rangwala SH, Isakson PC, Seibert K (1995) Expression and selective inhibition of the constitutive and inducible forms of human cyclo-oxygenase. Biochem J 305(Part 2): $479-484$

Giovannucci E, Rimm EB, Stampfer MJ, Colditz GA, Ascherio A, Willett WC (1994) Aspirin use and the risk for colorectal cancer and adenoma in male health professionals. Ann Intern Med 121: $241-246$
Grosch S, Tegeder I, Niederberger E, Brautigam L, Geisslinger G (2001) COX-2 independent induction of cell cycle arrest and apoptosis in colon cancer cells by the selective COX-2 inhibitor celecoxib. FASEB J 15: $2742-2744$

Hirata T, Ukawa H, Yamakuni H, Kato S, Takeuchi K (1997) Cyclooxygenase isozymes in mucosal ulcergenic and functional responses following barrier disruption in rat stomachs. $\mathrm{Br} J$ Pharmacol 122: $447-454$

Hunter T, Pines J (1994) Cyclins and cancer II: cyclin D and CDK inhibitors come of age. Cell 79: 573-582

Joe AK, Liu H, Suzui M, Vural ME, Xiao D, Weinstein IB (2002) Resveratrol induces growth inhibition, S-phase arrest, apoptosis, and changes in biomarker expression in several human cancer cell lines. Clin Cancer Res 8: $893-903$

Kargman SL, O’Neill GP, Vickers PJ, Evans JF, Mancini JA, Jothy S (1995) Expression of prostaglandin $\mathrm{G} / \mathrm{H}$ synthase-1 and -2 protein in human colon cancer. Cancer Res 55: 2556-2559

Kundu N, Smyth MJ, Samsel L, Fulton AM (2002) Cyclooxygenase inhibitors block cell growth, increase ceramide and inhibit cell cycle. Breast Cancer Res Treat 76: 57-64

Landis SH, Murray T, Bolden S, Wingo PA (1998) Cancer statistics, 1998 CA Cancer J Clin 48: 6-29

Liabakk NB, Talbot I, Smith RA, Wilkinson K, Balkwill F (1996) Matrix metalloprotease 2 (MMP-2) and matrix metalloprotease 9 (MMP-9) type IV collagenases in colorectal cancer. Cancer Res 56: 190-196

Lichtenstein DR, Wolfe MM (2000) COX-2-selective NSAIDs: new and improved? JAMA 284: 1297 - 1299

Martinez ME, McPherson RS, Levin B, Annegers JF (1995) Aspirin and other nonsteroidal anti-inflammatory drugs and risk of colorectal adenomatous polyps among endoscoped individuals. Cancer Epidemiol Biomarkers Prev 4: 703-707

Motokura T, Arnold A (1993) Cyclin D and oncogenesis. Curr Opin Genet Dev 3: $5-10$

Nelson AR, Fingleton B, Rothenberg ML, Matrisian LM (2000) Matrix metalloproteinases: biologic activity and clinical implications. J Clin Oncol 18: 1135 - 1149

Nomura H, Sato H, Seiki M, Mai M, Okada Y (1995) Expression of membrane-type matrix metalloproteinase in human gastric carcinomas. Cancer Res 55: 3263-3266

Oshima M, Dinchuk JE, Kargman SL, Oshima H, Hancock B, Kwong E, Trzaskos JM, Evans JF, Taketo MM (1996) Suppression of intestinal polyposis in Apc delta716 knockout mice by inhibition of cyclooxygenase 2 (COX-2). Cell 87: $803-809$

Peura DA (2002) Gastrointestinal safety and tolerability of nonselective nonsteroidal anti-inflammatory agents and cyclooxygenase-2-selective inhibitors. Cleve Clin J Med 69(Suppl 1): SI31 - SI39

Prosperi E (1997) Multiple roles of the proliferating cell nuclear antigen: DNA replication, repair and cell cycle control. Prog Cell Cycle Res 3: $193-210$

Ritland SR, Leighton JA, Hirsch RE, Morrow JD, Weaver AL, Gendler SJ (1999) Evaluation of 5-aminosalicylic acid (5-ASA) for cancer chemo- 
prevention: lack of efficacy against nascent adenomatous polyps in the Apc(Min) mouse. Clin Cancer Res 5: 855-863

Rozic JG, Chakraborty C, Lala PK (2001) Cyclooxygenase inhibitors retard murine mammary tumor progression by reducing tumor cell migration, invasiveness and angiogenesis. Int J Cancer 93: 497-506

Sawaoka H, Kawano S, Tsuji S, Tsujii M, Gunawan ES, Takei Y, Nagano K, Hori M (1998) Cyclooxygenase-2 inhibitors suppress the growth of gastric cancer xenografts via induction of apoptosis in nude mice. $\mathrm{Am} \mathrm{J}$ Physiol 274: G1061-G1067

Schwartz JI, Vandormael K, Malice MP, Kalyani RN, Lasseter KC, Holmes GB, Gertz BJ, Gottesdiener KM, Laurenzi M, Redfern KJ, Brune K (2002) Comparison of rofecoxib, celecoxib, and naproxen on renal function in elderly subjects receiving a normal-salt diet. Clin Pharmacol Ther 72: $50-61$

Sheng $\mathrm{H}$, Shao J, Kirkland SC, Isakson P, Coffey RJ, Morrow J, Beauchamp RD, DuBois RN (1997) Inhibition of human colon cancer cell growth by selective inhibition of cyclooxygenase-2. J Clin Invest 99: $2254-2259$

Sherr CJ (1996) Cancer cell cycles. Science 274: 1672 - 1677

Singh GK, Miller BA, Hankey BF (2002) Changing area socioeconomic patterns in US cancer mortality, 1950-1998: Part II - Lung and colorectal cancers. J Natl Cancer Inst 94: 916-925

Singh P, Velasco M, Given R, Wargovich M, Varro A, Wang TC (2000) Mice overexpressing progastrin are predisposed for developing aberrant colonic crypt foci in response to AOM. Am J Physiol Gastrointest Liver Physiol 278: G390 - G399

Singh P, Walker JP, Townsend Jr CM, Thompson JC (1986) Role of gastrin and gastrin receptors on the growth of a transplantable mouse colon carcinoma (MC-26) in BALB/c mice. Cancer Res 46: 1612-1616

Smalley W, Ray WA, Daugherty J, Griffin MR (1999) Use of nonsteroidal anti-inflammatory drugs and incidence of colorectal cancer: a population-based study. Arch Intern Med 159: $161-166$

Sutter T, Doi S, Carnevale KA, Arber N, Weinstein IB (1997) Expression of cyclins D1 and E in human colon adenocarcinomas. J Med 28: 285-309

Taketo MM (1998a) Cyclooxygenase-2 inhibitors in tumorigenesis (Part I). J Natl Cancer Inst 90: 1529-1536

Taketo MM (1998b) Cyclooxygenase-2 inhibitors in tumorigenesis (Part II). $J$ Natl Cancer Inst 90: 1609-1620

Tomozawa S, Nagawa H, Tsuno N, Hatano K, Osada T, Kitayama J, Sunami E, Nita ME, Ishihara S, Yano H, Tsuruo T, Shibata Y, Muto T (1999) Inhibition of haematogenous metastasis of colon cancer in mice by a selective COX-2 inhibitor, JTE-522. Br J Cancer 81: $1274-1279$

Toyoshima T, Kamijo R, Takizawa K, Sumitani K, Ito D, Nagumo M (2002) Inhibitor of cyclooxygenase-2 induces cell-cycle arrest in the epithelial cancer cell line via up-regulation of cyclin dependent kinase inhibitor p21. Br J Cancer 86: $1150-1156$
Tsujii M, DuBois RN (1995) Alterations in cellular adhesion and apoptosis in epithelial cells overexpressing prostaglandin endoperoxide synthase 2 . Cell 83: $493-501$

Tsujii M, Kawano S, DuBois RN (1997) Cyclooxygenase-2 expression in human colon cancer cells increases metastatic potential. Proc Natl Acad Sci USA 94: $3336-3340$

Tsujii M, Kawano S, Tsuji S, Sawaoka H, Hori M, DuBois RN (1998) Cyclooxygenase regulates angiogenesis induced by colon cancer cells. Cell 93: 705-716

Vihinen P, Kahari VM (2002) Matrix metalloproteinases in cancer: prognostic markers and therapeutic targets. Int J Cancer 99: 157-166

Waddell WR, Loughry RW (1983) Sulindac for polyposis of the colon. $J$ Surg Oncol 24: 83-87

Walker JP, Townsend Jr CM, Singh P, James E, Thompson JC (1986) The effect of aging on the growth of colon cancer. Mech Ageing Dev 37: 241 247

Williams CS, Mann M, DuBois RN (1999) The role of cyclooxygenases in inflammation, cancer, and development. Oncogene 18: 7908-7916

Williamson RC, Bauer FL, Oscarson JE, Ross JS, Malt RA (1978) Promotion of azoxymethane-induced colonic neoplasia by resection of the proximal small bowel. Cancer Res 38: 3212-3217

Wolfe MM (1998) Future trends in the development of safer nonsteroidal anti-inflammatory drugs. Am J Med 105: 44S - 52S

Wolfe MM, Lichtenstein DR, Singh G (1999) Gastrointestinal toxicity of nonsteroidal antiinflammatory drugs. $N$ Engl J Med 340: 1888 - 1899

Woodhouse EC, Chuaqui RF, Liotta LA (1997) General mechanisms of metastasis. Cancer 80: 1529-1537

Xu XM, Sansores-Garcia L, Chen XM, Matijevic-Aleksic N, Du M, Wu KK (1999) Suppression of inducible cyclooxygenase 2 gene transcription by aspirin and sodium salicylate. Proc Natl Acad Sci USA 96: 5292-5297

Yao M, Kargman S, Lam EC, Kelly CR, Zheng Y, Luk P, Kwong E, Evans JF, Wolfe MM (2003) Inhibition of cyclooxygenase-2 by rofecoxib attenuates the growth and metastatic potential of colorectal carcinoma in mice. Cancer Res 63: 586-592

Yao M, Song DH, Rana B, Wolfe MM (2002) COX-2 selective inhibition reverses the trophic properties of gastrin in colorectal cancer. Br J Cancer 87: $574-579$

Yoshimi N, Kawabata K, Hara A, Matsunaga K, Yamada Y, Mori H (1997) Inhibitory effect of NS-398, a selective cyclooxygenase-2 inhibitor, on azoxymethane-induced aberrant crypt foci in colon carcinogenesis of F344 rats. Jpn J Cancer Res 88: $1044-1051$

Yoshimi N, Shimizu M, Matsunaga K, Yamada Y, Fujii K, Hara A, Mori H (1999) Chemopreventive effect of $N$-(2-cyclohexyloxy-4-nitrophenyl)methane sulfonamide (NS-398), a selective cyclooxygenase-2 inhibitor, in rat colon carcinogenesis induced by azoxymethane. Jpn J Cancer Res 90: $406-412$ 